\title{
AS OPERAÇÕES DE CRÉDITO COMO FORMA DE DESENVOLVER PROJETOS PÚBLICOS
}

\section{Kátia Cristina de Oliveira ${ }^{1}$ Quésia Postigo Kamimura²}

Resumo: Pretende-se nesse trabalho propiciar aos municípios um entendimento sobre as operações de crédito interno e externo, uma vez que o financiamento público é uma essencial ferramenta na execução de programas públicos. Objetiva-se por meio de pesquisas documentais, especificar os tipos de financiamentos existente e demonstrar as exigências a serem cumpridas, bem como os processos e as entidades envolvidas, a fim de esclarecer os procedimentos adequados para que os municípios possam ter uma gestão eficiente da dívida pública, aliada a transparência das informações, minimizando assim os riscos financeiros e orçamentários.

Palavras-chave: Operações de crédito; Financiamentos; Municípios; Endividamento.

\footnotetext{
${ }^{1}$ Mestranda no Curso Profissional de Desenvolvimento Regional da Universidade de Taubaté, Brasil. E-mail: chrysobral@yahoo.com.br.

2 Graduada em Ciências Econômicas/Doutora em Saúde Pública pela USP, professora assistente do Mestrado Acadêmico em Planejamento e Desenvolvimento Regional da Universidade de Taubaté-UNITAU, Brasil. E-mail: qkamimura@gmail.com.
} 